\title{
KNOWLEDGE ACQUISITION: THE ROLE OF ORGANIZATION'S VISION A CASE OF TECHNOLOGY-BASED START-UP IN INDONESIA
}

\author{
Naufal Al Labib Tisyadi*)1, Dedy Sushandoyo*), and Retna Ayu Mustikarini Kencanasari*) \\ *) School of Business and Management ITB \\ Jl. Ganesa No.10, Lb. Siliwangi, Kecamatan Coblong, Kota Bandung, Jawa Barat 40132, Indonesia
}

\begin{abstract}
This study aims to uncover how Organization's vision (OV) can affect Knowledge Acquisition (KA). Qualitative research method is implemented to investigate a case of KA in technology-based Start-Up, namely e-Fishery. This study's data is collected by performing semi-constructed interviews several prominent figures in the company. Data analysis is done by thematic analysis to identify emerging themes and the interrelation between them. Findings of this research suggest that $\mathrm{OV}$ indirectly affects KA through influencing the way organizations interact with the customers, which in turn affects KA performance. Furthermore, this study argues the positive influence of customer oriented OV to KA success. This study contributes to KA literature by providing elaboration on $\mathrm{OV}$ influence and its role in the interaction inside organization-customers settings.
\end{abstract}

Keywords: knowledge acquisition, organization's vision, interaction, digital startup, innovation

\begin{abstract}
Abstrak: Penelitian ini bertujuan menguak peran Visi Organisasi (OV) dalam Akuisisi Pengetahuan (KA). Metoda riset kualitatif diimplementasikan di dalam riset ini untuk menginvestigasi praktik KA di dalam sebuah perusahaan Start-Up teknologi yang bernama e-Fishery. Data yang digunakan di dalam penelitian ini didapatkan dengan melakukan wawancara kepada beberapa figur penting di dalam perusahaan tersebut. Analisis tematik diimplementasikan untuk mengidentifikasi tema-tema yang muncul dari data serta keterkaitan diantaranya. Temuan dari penelitian ini menunjukan bahwa OV secara tidak langsung berdampak kepada kualitas KA dengan cara mempengaruhi cara sebuah organisasi berinteraksi dengan pelanggan. Lebih jauh lagi, penelitian ini berargumen bahwa OV yang berorientasi kepada pelanggan memiliki pengaruh positif terhadap suksesnya praktik KA. Penelitian ini berkontribusi kepada literatur KA dengan menyediakan penjelasan mengenai pengaruh dan peran dari OV di dalam kesuksesan KA pada interaksi organisasi ke pelanggan.
\end{abstract}

Kata kunci: akuisisi pengetahuan, visi organisasi, interaksi, start-up digital, inovasi

\footnotetext{
${ }^{1}$ Corresponding author:

Email: naufal_al@sbm-itb.ac.id
} 


\section{INTRODUCTION}

Knowledge has been recognized as a significant factor in organizational growth. It has been associated with the increase of company's absorptive capabilities (Osoro et al. 2016; Larrañeta et al. 2017), establishment of competitive advantage (Laursen et al. 2016; Yli-Renko et al. 2001), improvement of new product development (Yli-Renko et al. 2001), innovative capability (Prayogo and Nirawati, 2019), the creation of radical innovation (Zhou and Li, 2012), and organizational sustainability (Xie et al. 2020). Firms may acquire knowledge internally by leveraging existing knowledge residing within their members (López-Sáez et al. 2010) or externally from entities outside organizational boundaries (Nonaka and Takeuchi 1996). Firms that invest in KA will have a wide range of knowledge that offers variability to ascertain innovative capability which is useful in obtaining market success (Migdadi et al. 2017). However, merely implementing KA will not necessarily produce a meaningful result (CruzGonzález et al. 2015). At times, a company could find itself swamped in unclear and opaque information as a consequence of KA (McKelvie et al. 2018). Or worse the inbound knowledge are useless therefore resource utilized for its acquisition are wasteful (McKelvie et al. 2018). Even more problematically if it continues to the development of the unneeded product which is one of the primary reasons of new business failure (cbinsight, 2021). Nevertheless, amid its complexity, the proof of KA benefit is far too compelling to be dismissed. However, the existence of contradicting findings of KA function indicates the need for further understanding.

Many have made effort to identify precursors of KA success. Some investigate its relation to social capital such as trust and relationship (Guo et al. 2019; Ortiz et al. 2017). Another found that differing knowledge source such as customer, supplier, partner, university, and investor yield distinct result which value depends on the specific context of the company (Cruz-González et al. 2015). Similar case occurs for knowledge breadth and depth. Some argue the benefit of knowledge depth for the pursue of radical innovation (Zhou and Li, 2012) while others posit knowledge breadth as a significant factor of company's innovativeness (Migdadi et al. 2017). This study, on the other hand, tries to approach the topic of KA at a more grounded level. Particularly, this study aims to uncover the potential success factor of KA in the organization's foundational level such as OV.
Despite OV and KA popularity in the business management and social science literature, study that specifically investigate their connection is extremely scarce. It is as if both have no connection worth examining. For example, a search using both concepts as keywords in SCOPUS database yields only seven results, with only three that are relevant to the topic (e.g., Kim \& Lee, 2010; Narayanan \& Rajaratnam, 2019; Shahzad et al., 2013). In their conceptual paper, Shahzad et al. (2013) made a compelling remark to argue the importance of the connection between $\mathrm{OV}$ and KA. They argue that knowledge intensive initiative requires commitment. Not only in its execution but also in the management's resolve for resource allocation. Shahzad et al. (2013) posit OV as an important precursor for knowledge intensive practice. The implementation of KA is resource demanding, both tangibly and intangibly. For instance, Kong (2015) pointed out that KA requires interaction which demands time, infrastructure, and social prowess to ensure successful execution. Therefore, implementing KA presents a challenging task to perform. And even more so if it required interaction between the company and the external entities (Kong 2015).

$\mathrm{OV}$ is a popular topic in management literature, especially in the last two decades. OV is associated with organizational growth (Perkins, Lean, and Newbery 2017). Primarily, OV is defined as an imagery of desired future that acts as an ultimate objective to dictate organization's purpose and to focus organization's effort and resource allocation (Snyder and Graves 1994). The existence of OV galvanized the organization's members' motivation and solidify their commitment to organization's cause (Haque, Titiamayah, and Liu 2016; Chih et al. 2018). OV's ability to situate the condition of organization's members is tied together with aforementioned argumentation by Shahzad et al. (2013) which posits OV's as an important factor to motivate organization's members to ensure KA performance. With that in mind this study set an exploratory mindset to tackle the question of "how can OV affect KA?" Therefore, this study aims to contribute to the academic discourse by filling the gap in KA literature by presenting insights regarding the role of OV to KA. Moreover, this study aims to create impact in managerial department by providing useful information, particularly for prospective entrepreneur to both refine their KA practice and as a factor to consider during a business's early development. To 
achieve that, this study implements a qualitative method with inductive approach to complement its exploratory nature (Saunders et al. 2019).

This study identifies KA practice in Indonesia's technology-based start-up (namely e-Fishery) as an appropriate case to fulfill the aims of this research. e-Fishery is a technology-based Start-up focusing on the aquaculture industry. Their business vision is considerably non-self-centric. It focuses on their customers' well-being instead of the organization's prosperity. Despite that, they managed to obtain rapid growth during their seven years of operation. Additionally, they indicate KA success by producing a highly consumed product inspired by direct interaction with their customers. e-Fishery's market condition is also unique as it portrays a large technology literacy gap between e-Fishery (a high-tech technology producer) and the customer (mostly consist of population in a less developed rural area). These combinations of characteristics deemed e-Fishery as a prominent entity to be investigated, particularly for this study's purpose.

The remainder of this paper consists of the methodology adopted to investigate the case of e-Fishery is presented. Furthermore, the findings of this study are announced and discussed. Lastly, limitations and potential future inquiries will be presented as a conclusion.

\section{METHODS}

The aims of this study are to tackle the question of "how OV can affect KA?" Therefore, this study set off with exploratory motivation. For this purpose, this study implements qualitative research method. Following the guidelines provided by Yin (2009) this research employs a single case study research design to accommodate its exploratory nature. Furthermore, the method is considered appropriate due to the contemporary characteristics of the phenomena and the researchers positioning as uninvolved investigator. Moreover, the reasoning behind the decision to use singular case is due to the uniqueness in the characteristics of e-Fishery's case, which made it considerably rare to occur elsewhere. As one of the emerging prominent digital Start-up in aquaculture, e-Fishery managed to achieve rapid growth in a considerably short period of 6 years. They started their business in 2013 by offering IoT augmented automatic fish feeder to their prospective customers. Despite the lack of technological development in aquaculture prior to e-Fishery's inception among their intended customers which caused them hardship during initial penetration e-Fishery they still managed to expand their reach to more than 20 provinces in Indonesia.

Furthermore, e-Fishery demonstrates their business prowess by producing a thriving variety of products aside from fish feeders ranging from fish product e-commerce and fish feed commerce to fish farmers financial consulting. Those products are well received and widely consumed by their customers, generating up to $60 \%$ of their current income, indicating a product's effectiveness, which signals high innovation performance. Moreover, testimonies from e-Fishery's CEO suggested that some of their various products were inspired by their customer feedback, which was obtained through direct interaction. Furthermore, he indicated that the reason behind their insistence on direct interaction with their customers is due to the OV. These unique qualities placed e-Fishery as a potent specimen to be extensively studied to understand the connection between $\mathrm{OV}$ and KA further.

This study uses both primary and secondary data. Primary data for this study is collected by performing in-depth interviews with key members of e-Fishery (presented in Table 1). Primary data gathering is done from November 2019 to February 2020. The interview occurs in e-Fishery's main office in Bandung and done in a semi-structured manner. The purpose of the interview is to uncover the way e-Fishery operates. The interview content covers various aspects, such as companies' objectives, business development, product development, and e-Fishery's relationship with the customers. The duration of the interview varies from 37 minutes to 102 minutes.

The secondary data used in this study is taken from the previous research done by Maulana (2018) as his undergraduate thesis. The purpose of the utilization of this data is to compliment the primary data. His research highlight e-Fishery's Knowledge Transfer during Technology Adoption Process. Interview data taken from his research consisted of interviews with 6 farmers and e-Fishery's Field Officer. The content of those data contains information regarding the interaction between e-Fishery and their customers, which is appropriate to be incorporated for the purpose of this study. However, farmers' interview data from that research 
are considerably short in duration (around 6 minutes to 32 minutes). This is due to the utilization of structured interview method which made it more direct and to the point. Regardless, the content of the farmers responses remains adequate for the purpose of this study. Another secondary data is collected from the website content as reference to e-Fishery's organization's vision. This data is taken as comparative point to measure whether e-Fishery operates according to its vision.

This study implements the 'no theory' approach by Eisenhardt (1989). This approach provides exploratory room for data interpretation by minimizing theoretical restriction, which allows novel ideas to emerge. Further, the interview result is transcribed and analyzed to identify emerging patterns. Data analysis is done with thematic analysis method. Subsequently, the data is analyzed using thematic analysis. This method is used to uncover emerging theme related to the purpose of this study. The emerging theme is later put together to find explanatory analysis suitable to explain the phenomena in the data (Saunders, Lewis, and Thornhill 2019). Lastly, previous literature is collected and reviewed to provide theoretical groundings sustaining the result of this research. However, to clarify, a certain disclaimer is necessary to be addressed: The subject investigated in this study is the interaction between e-Fishery and its customers. What is referred to as 'interaction' in this study are only ones that are officially sanctioned by e-Fishery (e.g., door-to-door marketing, routine checkup, after-sales service).

\section{RESULTS}

This study aims to uncover the way OV can affect KA. Thematic analysis is done to analyze the data which summarized in Table 2. From the analysis, we found that there are three primary themes which are organization's foundation, interaction, and KA performance. Organization's foundation represented organization's core value which shape the organization purpose and behavior. It affects the way organization interact with the customers, which in turn, affect KA performance. The interplay between these three aspects is shown in Figure 1. In the case of e-Fishery, interaction with customer is done primarily in an informal mechanism. The way e-Fishery does its interaction later affect the performance of KA.

\section{Organizational Foundation}

e-fishery's vision was mentioned verbally in the interview. However, they also present their vision in their website. Presented in the following are e-Fishery's vision, which was taken directly from their website (verbatim translation): To contribute to the fulfillment of world sustenance through aquaculture; To become a solution to a fundamental aquaculture issue by providing affordable technology; To reduce socio and economic disparities through inclusive digital economy.

From what is presented above, it can be argued that e-fishery's OV is non-self-centric. This is also corresponding to the vision described by DS (Business Development Strategist) who mentioned

Table 1. List of Interviewees

\begin{tabular}{|c|c|c|c|c|}
\hline Position & Initials & Sex & Topic of Interview & Interview Duration \\
\hline Founder/CEO & $\mathrm{GH}$ & $\mathrm{M}$ & $\begin{array}{l}\text { e-Fishery general outlook, technology } \\
\text { adoption, business development, customer } \\
\text { interaction }\end{array}$ & 62 minutes \\
\hline Business Development Strategist & DS & M & $\begin{array}{l}\text { Technology adoption, customer interaction, } \\
\text { business development, product development }\end{array}$ & 102 minutes \\
\hline Head of Product Department & IN & M & $\begin{array}{l}\text { Technology adoption, customer interaction, } \\
\text { business development }\end{array}$ & 64 minutes \\
\hline Head of Engineering Department & AS & M & $\begin{array}{l}\text { Customer interaction, business development, } \\
\text { product development }\end{array}$ & 37 minutes \\
\hline
\end{tabular}


Table 2. Thematic analysis summary

\begin{tabular}{|c|c|c|c|}
\hline Primary Code & $\begin{array}{l}\text { Secondary } \\
\text { Code }\end{array}$ & Initial Code & Quotation Example \\
\hline \multirow[t]{6}{*}{$\begin{array}{l}\text { Organization's } \\
\text { Foundation }\end{array}$} & \multirow[t]{2}{*}{$\begin{array}{l}\text { Organization's } \\
\text { Vision }\end{array}$} & Social Economy & $\begin{array}{l}\text { "The purpose our technology is to create social economic impact for } \\
\text { fish farmers" - e-Fishery's Head of Business Development }\end{array}$ \\
\hline & & $\begin{array}{l}\text { Becoming } \\
\text { Solution }\end{array}$ & $\begin{array}{l}\text { "We aim to become the solution not merely providing solution to the } \\
\text { fish farmers' problems" - e-Fishery's Head of Business Development }\end{array}$ \\
\hline & \multirow[t]{2}{*}{$\begin{array}{l}\text { Business } \\
\text { Orientation }\end{array}$} & $\begin{array}{l}\text { Helping farmers } \\
\text { not only } \\
\text { profiting the } \\
\text { company }\end{array}$ & $\begin{array}{l}\text { "from the beginning we develop our technology to solve farmers' } \\
\text { problem. Our business is aimed to not only produce financial benefit } \\
\text { but also useful to the farmers" - e-Fishery's CEO }\end{array}$ \\
\hline & & Farmer First & $\begin{array}{l}\text { "We have a culture called 'farmers first'. We lead people here to } \\
\text { always identify farmers' needs" - e-Fishery's Head of Business } \\
\text { Development }\end{array}$ \\
\hline & \multirow[t]{2}{*}{$\begin{array}{l}\text { Business } \\
\text { Strategy }\end{array}$} & Offline First & $\begin{array}{l}\text { "Our customers are not familiar with automated technology, while we } \\
\text { are exposed to it all the time. Therefore, we implement 'offline first' } \\
\text { approach to familiarize our customers to our product" - e-Fishery's } \\
\text { Head of Engineering }\end{array}$ \\
\hline & & $\begin{array}{l}\text { Community } \\
\text { activation }\end{array}$ & $\begin{array}{l}\text { "our user's knowledge of the product is vary, some of them don't have } \\
\text { a complete understanding of our product.... that is why we develop } \\
\text { our business model from technology based to community activation. } \\
\text { We want to increase their skill" - e-Fishery's Head of Business } \\
\text { Development }\end{array}$ \\
\hline \multirow[t]{8}{*}{ Interaction } & \multirow[t]{2}{*}{$\begin{array}{l}\text { Interaction } \\
\text { Mechanism }\end{array}$} & $\begin{array}{l}\text { Informal } \\
\text { interaction }\end{array}$ & $\begin{array}{l}\text { "we don't have SOP to teach the farmers ... we scan their condition } \\
\text { and teach them accordingly" - e-Fishery's Field Officer }\end{array}$ \\
\hline & & $\begin{array}{l}\text { Formal } \\
\text { interaction }\end{array}$ & $\begin{array}{l}\text { "we have information people can access in our website ... we also } \\
\text { occasionally participate in an exhibition to introduce our product" - } \\
\text { e-Fishery's Product Manager }\end{array}$ \\
\hline & \multirow[t]{2}{*}{$\begin{array}{l}\text { interaction } \\
\text { frequency }\end{array}$} & $\begin{array}{l}\text { Routine } \\
\text { Visitation }\end{array}$ & $\begin{array}{l}\text { "every team must do routine site visitation. Marketing team in } \\
\text { particular, must visit the site often. HR and Finance team must visit } \\
\text { the site at least once every two or three month" - e-Fishery's CEO }\end{array}$ \\
\hline & & $\begin{array}{l}\text { Communication } \\
\text { with FO }\end{array}$ & $\begin{array}{l}\text { "we often meet, we often communicate, "Mr Taja what should we do? } \\
\text { or "Mr Taja why can't I setting the feeder properly?" - Fish Farmers } 4\end{array}$ \\
\hline & \multirow[t]{2}{*}{$\begin{array}{l}\text { Interaction } \\
\text { Tools }\end{array}$} & $\mathrm{ICT}$ & "we use WhatsApp most of the time" - e-Fishery's Field Officer \\
\hline & & $\begin{array}{l}\text { Face-to-face } \\
\text { communication }\end{array}$ & $\begin{array}{l}\text { "site visitation is must. I often visit the site and converse with the } \\
\text { farmers" - e-Fishery's CEO }\end{array}$ \\
\hline & \multirow[t]{2}{*}{$\begin{array}{l}\text { Interaction } \\
\text { Topic }\end{array}$} & $\begin{array}{l}\text { Farming } \\
\text { Insights }\end{array}$ & "they help us in cultivation knowledge" - Fish Farmers 3 \\
\hline & & Small Talk & $\begin{array}{l}\text { "sometimes we were sent to the site just to catch up with farmers ... } \\
\text { it's to maintain relationship ... sometimes talking about farming is } \\
\text { boring." - e-Fishery's Field Officer }\end{array}$ \\
\hline \multirow[t]{3}{*}{$\begin{array}{l}\text { Knowledge } \\
\text { Acquisition } \\
\text { Performance }\end{array}$} & \multirow[t]{3}{*}{$\begin{array}{l}\text { Inbound } \\
\text { Feedback }\end{array}$} & $\begin{array}{l}\text { Sector context } \\
\text { feedback }\end{array}$ & $\begin{array}{l}\text { "once, there is farmer who deliberately didn't use our product because } \\
\text { he fears early harvest. We honestly thought the quicker the better. } \\
\text { As it turns out fish farmers should sync their harvesting schedule } \\
\text { to the pattern of the existing market practice so that their fish can } \\
\text { be sold timely with the right price" - e-Fishery's Head of Business } \\
\text { Development }\end{array}$ \\
\hline & & $\begin{array}{l}\text { Product } \\
\text { feedback }\end{array}$ & $\begin{array}{l}\text { "The cable is prone to be bitten by rats, we suggest that the cable is } \\
\text { rat resistance" - Fish Farmers } 1\end{array}$ \\
\hline & & $\begin{array}{l}\text { Customer's } \\
\text { behavior } \\
\text { feedback }\end{array}$ & $\begin{array}{l}\text { "it turns out that farmers perception on their fish feed needs is } \\
\text { changeable. For example, they ask for } 25 \text { tons fish feed and change } \\
\text { it to } 20 \text { tons after some time. And they are unwilling to pay for the } \\
\text { remainder } 5 \text { tons. Perhaps they lack understanding of the business } \\
\text { term, especially in partnership." - e-Fishery's Head of Business } \\
\text { Development }\end{array}$ \\
\hline
\end{tabular}


Table 2. Thematic analysis summary (continue)

\begin{tabular}{|c|c|c|c|}
\hline Primary Code & $\begin{array}{l}\text { Secondary } \\
\text { Code }\end{array}$ & Initial Code & Quotation Example \\
\hline & \multirow[t]{2}{*}{$\begin{array}{l}\text { New Product } \\
\text { from } \\
\text { Feedback }\end{array}$} & financing & $\begin{array}{l}\text { "our financing service was not in our masterplan at all. We got the } \\
\text { idea from a complaint of one of the farmers. He mentioned that } \\
\text { our feeder increases his productivity, but he does not get wealthier. } \\
\text { Therefore, we asked him to investigate his expenditure ... as it turns } \\
\text { out, he was unnecessarily spending his money on the interest in fish } \\
\text { feed fee. That inspire us to create financing service to help them } \\
\text { obtain credit scoring so that they can have financial support from } \\
\text { local bank, instead of peer-to-peer lending." - e-Fishery's CEO }\end{array}$ \\
\hline & & e-Fishery Fresh & $\begin{array}{l}\text { "we made e-Fishery Fresh to mitigate the problem in the market. We } \\
\text { can't sale our feeder if there is no guarantee that the farmers will use } \\
\text { it." - e-Fishery's Head of Business Development }\end{array}$ \\
\hline & \multirow[t]{2}{*}{$\begin{array}{l}\text { Understanding } \\
\text { the context } \\
\text { of farmer's } \\
\text { problem }\end{array}$} & $\begin{array}{l}\text { understand } \\
\text { supply chain } \\
\text { problem }\end{array}$ & $\begin{array}{l}\text { "farmers sell their fish through a middleman. This middleman only } \\
\text { willing to buy fish on a specific date. This is what hinders farmers } \\
\text { from increasing their productivity." - e-Fishery's Head of Business } \\
\text { Development }\end{array}$ \\
\hline & & $\begin{array}{l}\text { understand } \\
\text { cultivation } \\
\text { context }\end{array}$ & $\begin{array}{l}\text { "cultivating catfish and shrimps are different. Our feeder is used more } \\
\text { to cultivate shrimp because shrimps require equal growth. Therefore, } \\
\text { it is more urgent. Catfish on the other hand, can be harvested partially. } \\
\text { They can be harvested in several grades of sizes." - e-Fishery's Head } \\
\text { of Business Development }\end{array}$ \\
\hline
\end{tabular}

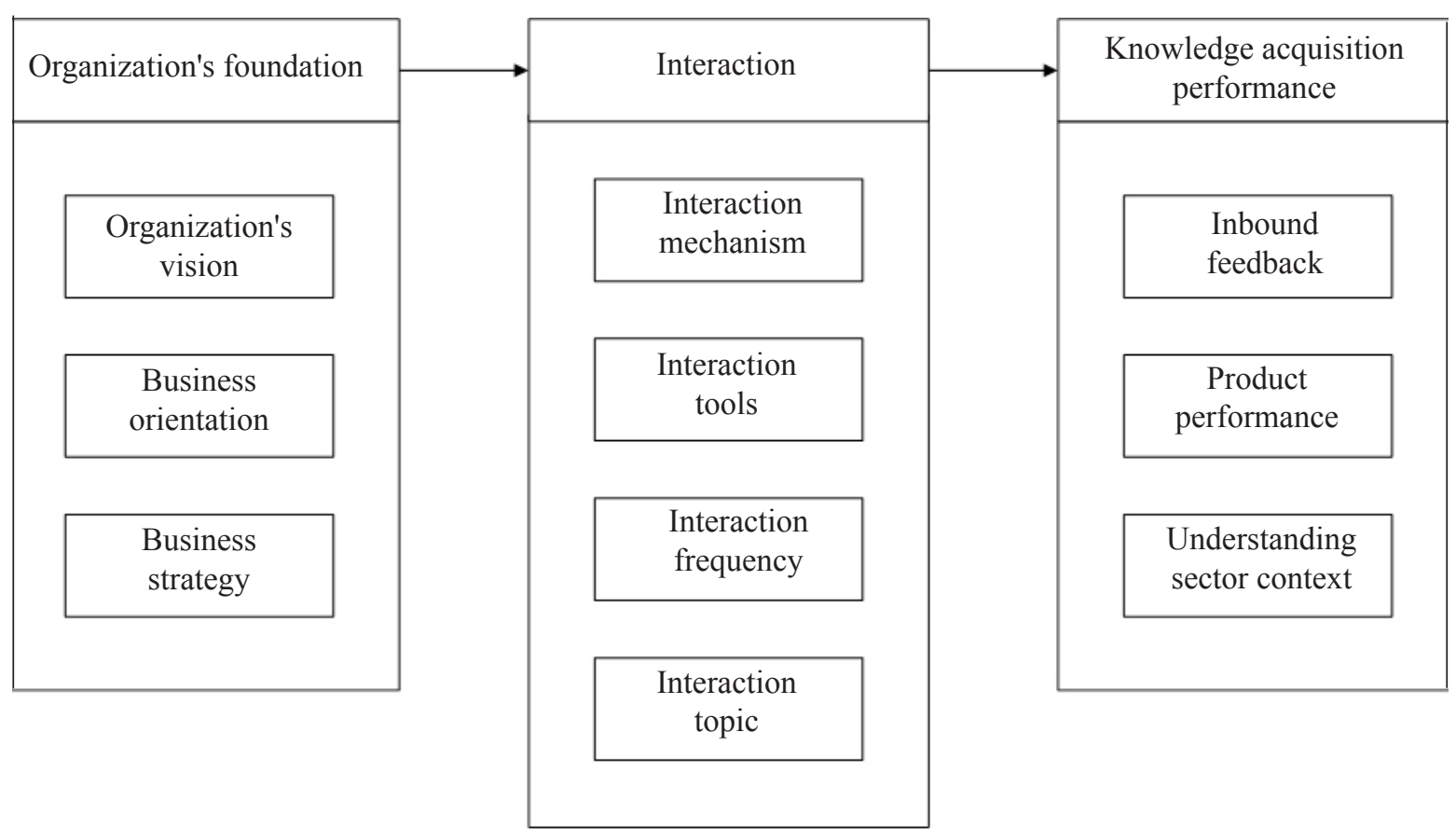

Figure 1. OV to KA Conceptual Model (developed from e-Fishery's data)

about the intention to positively impact the social economy and becoming the solution for farmers problem. The consistency prevails in the "farmers first" organization's culture. It was described that the culture shapes the behavior of the members to prioritize farmers' need in every decision making. It was indicated that the implementation of that culture orients e-Fishery's business to prioritize farmers well-being instead of profit making. The effect of this culture is also shown by the determination of the company to keep going back and forth to the farmer's site. Subsequently, e-fishery implement "offline first" as strategy for initial penetration. The execution of this strategy can be interpreted in two folds, first, it might 
be one of the manifestations of the "farmers first" culture or second, it may also be a sensible approach to mitigate large technology gap between e-fishery and its intended customer. However, e-fishery also implement "community activation" strategy, which pivot on a community building to improve customers familiarity to the product and also their prowess in fish cultivation. By doing community activation, e-Fishery aims to make impact to the farmers life, not only by providing a technological know-how to familiarize the farmers to their product, but also to improve their overall fish farming practice for the better.

Furthermore, they also change their business model from direct selling to subscription. Subscription model enables e-Fishery to optimize the capitalization of their product. For example, by doing subscription they seize the right to perform routine maintenance. This is done to improve the feeder utilization and to maintain good customer experience. However, from farmers perspective subscription approach is more economic as it enables them to access e-Fishery's technology cheaply. It is arguable that e-Fishery's business strategy is a mix between farmers prioritization and income generation.

\section{Interaction}

A line can be drawn from organization's foundation to the way e-fishery's done their interaction. It was mentioned by the CEO and the Head of Engineer that obtaining feedback from the farmers is paramount. In respond to that, e-fishery's mandate all their members to do routine site visitation. Especially the marketing and field team (site technician and field officer). Frontliners are demanded to do compulsory monthly visit. The objective is to maintain relationship with the farmers and to scan current emerging problems. Routine visitation also being used as tools to convey software and product updates. Interaction mechanism that is primarily used by e-fishery is informal interaction. They leverage faceto-face two-way communication. Performing direct two-way interaction helps them to obtain an in-depth insight regarding farmers daily struggles. The only formal interaction they did to the customer is on the exhibition or one-way communication from website.

Maintaining communication is necessary for e-Fishery. Therefore, e-Fishery provide a communication channel through social media such as WhatsApp. One of the farmers testify that they maintain communication with the technician. Another interesting finding is the variety of topic that could occur in the interaction between e-Fishery and the farmers. The Field Officer testify that sometimes they were sent to the site just to have a chat with the farmers. He mentioned that the objective to that is to "maintain relationship" and to "up-sales". e-Fishery also tries to provide education regarding fish cultivation which was highly regarded by one of the farmer's remark who consider that as a form of "support" for the farmers.

\section{Knowledge Acquisition Performance}

KA is a learning process. In this analysis we indicate KA performance by investigating the amount and type of inbound information from customers and how they leverage those feedback. Feedback obtained from customers is varied. It describes customer's behavior, the contextual problem of aquaculture sector, and things to improve from the existing product. The data suggest that the procurement of these feedback is enabled by the interaction they did, particularly the use of informal mechanism. For once, they obtain the information regarding the contextual problem in the aquaculture sector through direct face-to-face interaction with the farmers. That information is shown to be useful for product development since it inspires e-fishery to create "e-fishery fresh" and "feedfund". Moreover, it was easier for the farmers to deliver their complaint or suggestion regarding the current product performance since they are frequently visit the site. The establishment of online communication channel also enables e-fishery to perform quick responds should the farmers experience difficulties.

This study aims to uncover how OV can affect KA. The result of the analysis shows indirect relationship of OV to KA. OV affect organization's ways of interaction through its influence on business orientation and strategy. The OV adopted by e-fishery is nonself-centric, this is similar to the categorization of market-oriented entrepreneurial approach (Migdadi et al. 2017). Market oriented is documented to have a positive relationship to organizational performance, particularly in terms of delivering innovation to the market (Migdadi et al. 2017). The current study adds to the entrepreneurial literature by providing possible explanation of why market-oriented entrepreneurial approach strive in the market. Findings on current research also suggest that $\mathrm{OV}$ affect the member's commitment to the organizational cause. Thus, it 
supports findings from Haque et al. (2016) who suggest that the content of vision affect employee's commitment. e-fishery's commitment is demonstrated by the willingness to prioritize farmer's needs. Their resolve to establish interaction to the farmers also driven by their sense of duty to become the solution of farmers problems which resonates to the argumentation by Shahzad et al. (2013) who contend OV as necessary driving force for knowledge intensive initiative.

As a consequence of their vision, e-fishery's interaction becomes frequent. Frequent interaction is associated with KA success particularly because it aids the establishment of relationship and trust (Kong 2015; Lee et al. 2020). Furthermore, findings of the current study suggest the impact of informal interaction to the knowledge sharing. This resonates with findings from Weijs-Perrée et al. (2020) who found an informal and unstructured interaction as potent to invoke knowledge sharing behavior. More importantly, findings of the current research also add to the literature by suggesting the importance of interaction topic for the success of KA. Careful use of interaction topic may improve the chance to establish solid relationship to the customer which may lead to knowledge sharing intent. Furthermore, face-to-face interaction stimulates an indepth conversation which leads to a crucial knowledge sharing. Particularly, the findings of the current study suggest that contextual knowledge regarding aquaculture sector is mostly delivered during face-toface interaction.

KA is a learning process. One of the ways to decide whether learning occurs is by checking whether there is a behavioral change (Lipshitz, Popper, and Friedman 2002). Lipshitz et al. (2002) argues that productive learning occurs when the entity managed to identify and correct mistakes. In the case of e-fishery that pattern of behavior occurs. One of which is when they change their mindset after realizing that their simplistic thinking of "the quicker the harvest the better" does not resonates with the actual market situation. Their behavioral change indicate learning process. Similar incidence occurs when they were inspired to develop financing service after they were encounter farmers complaint. Even so, associating OV to the success of their learning process cannot be concluded hastily. However, at least it can be argued that OV enables e-fishery to conduct interaction that provide stream of rich inbound feedback.

\section{Managerial Implications}

This study produces several managerial implications. It was demonstrated above that $\mathrm{OV}$ indirectly affect KA performance through shaping the way a company interact with their intended customer. Particularly, this study highlights that the content of the OV affect the company's business orientation and its strategy. This is a useful insight for managerial, especially ones that are in the middle of business initiation. Crafting OV may later affect business practice significantly. Content of organizational vision determines the focus of business practice, which may vary from market share, product, or customer focus. These types of content may affect an organization's ability to interact with their customers. Therefore, a prospective entrepreneur should carefully consider the content of their organizational vision prior to business initiation, mainly if they aim to leverage customers' insight as inspiration for innovation. Moreover, the importance of organizational vision's clarity to the organization's members is pertinent to be emphasized. That way organization's members may embody the spirit of the organization and behave in a vision-coherent manner. The findings of the current study suggest that a non-self-centric customer oriented OV may indirectly shape the company's interaction so that they can obtain comprehensive understanding on their market condition. Moreover, OV affect members commitment to the organizational cause.

Correct implementation of OV may help manager to develop a less selfish behavior by allowing the member to transcend their personal interest. Findings of the current study suggest that customers might become a useful source of insight to inspire new business opportunities regardless of their expertise or technological prowess. Management should carefully consider how organizations translate customer feedback so that organizations may avoid fuzzy and misleading information. This study suggests that management might improve that ability by implementing an appropriate organizational vision to create productive interaction. The organization might focus solely on improving customer's trust by engaging in a more informal interaction with carefully selected interaction topics. 


\section{CONCLUSIONS AND RECOMMENDATIONS}

\section{Conclusions}

This study aims to tackle the question of how OV can affect KA performance. In response to that, this study found that OV indirectly affects KA performance by influencing organization's business strategy and the way it interacts with the customer. More importantly, the way organization shapes its interaction with its intended customer determined the quality of inbound feedback. This study closely investigates KA practice in Indonesia's technology-based Start-up namely e-Fishery to fulfill its objectives. As result, this study proposes conceptual model depicting the way $\mathrm{OV}$ affects KA along with the corresponding components. Furthermore, this study found that the way OV affects KA might be closely related to the OV orientation. For example, the current study closely examines the implementation of a non-self-centric OV. This drives the company to closely follows their customer's needs thus enable them to spot new business opportunity. Moreover, this study found the connection of OV to interaction, particularly in the way it shapes interaction topic and mechanism which in turn develop trust among customers that subsequently enable organization to establish meaningful interaction with their customers.

\section{Recommendations}

This study opens opportunity for potential research venture. Firstly, future research may attempt to identify the most significant OV influential attribute to the KA. Secondly, due to the focus of the non-self-centric OV undertaken by this study, future research focusing on OV that is tilted towards profit-oriented might be a potential area to be explored. Thirdly, future research might investigate the role of $\mathrm{OV}$ in the interaction dynamic between organization and other external entities such as supplier, partners, and rival. Subsequently, this study limits its analysis by eliminating leader's vision as employee's motivating factor. Leadership is suggested to affect both employee's motivation and organizational practice (Rahmawati, Satria, and Purnaningsih 2018; Rosiana, Hubeis, and Cahyadi 2020). Therefore, it is of benefit to direct future endeavor to investigate how leader's vision and leadership style affect KA.

\section{REFERENCES}

cbinsight. 2021. Why startups fail: Top 20 reasons 1 CB Insights. https://www.cbinsights.com/research/ startup-failure-reasons-top/. [22 Mar 2021]

Chih $\mathrm{Y}$ et al. 2018. Interactive effects of supportive leadership and top management team's charismatic vision in predicting worker retention in the Philippines. Journal of Construction Engineering and Management 144 (10): 04018095. https://doi.org/10.1061/(asce) co.1943-7862.0001553.

Cruz-González J, Pedro L, Jose EN. 2015. Absorbing knowledge from supply-chain, industry and science: the distinct moderating role of formal liaison devices on new product development and novelty. Industrial Marketing Management 47: 75-85. https://doi.org/10.1016/j. indmarman.2015.02.036.

Eisenhardt KM. 1989. Building theories from case study. Academy of Management Journal 14 (4): 532-50. https://doi.org/10.1016/s01406736(16)30010-1.

Guo Y, Lifang W, Miao W, Xiaodi Z. 2019. The mediating role of environmental innovation on knowledge acquisition and corporate performance relationship-a study of SMEs in China. Sustainability (Switzerland) 11(8). https:// doi.org/10.3390/su11082315.

Haque Md, Angela T, Lu L. 2016. Leadership \& organization development journal the role of vision in organizational readiness for change and growth for authors the role of vision in readiness for change. Leadership \& Organization Development Journal 37(7): 983-999. http:// dx.doi.org/10.1108/LODJ-01-2015-0003.

Kim S, Hyangsoo L. 2010. Factors affecting employee knowledge acquisition and application capabilities. Asia-Pacific Journal of Business Administration 2(2): 133-152. https://doi. org/10.1108/17574321011078184.

Kong E. 2015. A qualitative analysis of social intelligence in nonprofit organizations: external knowledge acquisition for human capital development, organizational learning and innovation. Knowledge Management Research and Practice 13(4): 463-474. https://doi. org/10.1057/kmrp.2013.63.

Larrañeta B, José LGG, Rocio A. 2017. Early efforts to develop absorptive capacity and their performance implications: differences among 
corporate and independent ventures. Journal of Technology Transfer 42 (3): 485-509. https:// doi.org/10.1007/s10961-016-9488-1.

Laursen K, Francesca M, Toke R. 2016. A matter of location: the role of regional social capital in overcoming the liability of newness in R\&D acquisition activities. Regional Studies 50 (9): 1537-50. https://doi.org/10.1080/00343404.201 5.1041370

Lee YLA, Ashish M, Philip JR, Piyush S. 2020. Demystifying the differences in the impact of training and incentives on employee performance: mediating roles of trust and knowledge sharing. Journal of Knowledge Management 24 (8): 1987-2006. https://doi.org/10.1108/JKM-042020-0309.

Lipshitz R, Micha P, Victor JF. 2002. A multifacet model of organizational learning. The Journal of Applied Behavioral Science 38 (1): 78-98. https://doi.org/10.1177/0021886302381005.

López-Sáez P, José EN, Gregorio M, Jorge C. 2010. External knowledge acquisition processes in knowledge-intensive clusters. Journal of Knowledge Management 14(5):690-707 https:// doi.org/10.1108/13673271011074845.

Maulana RD. 2018. Evaluation on the effectiveness on technological transfer in indonesian aquaculture industry: case study of E-Fishery, [Bachelors' Thesis]. Bandung: Institut Teknologi Bandung.

McKelvieA, Johan W,AnnaB.2018. Externally acquired or internally generated? knowledge development and perceived environmental dynamism in new venture innovation. Entrepreneurship: Theory and Practice 42(1):24-46. https://doi. org/10.1177/1042258717747056.

Migdadi MM et al. 2017. An empirical examination of knowledge management processes and market orientation, innovation capability, and organisational performance: Insights from Jordan. Journal of Information and Knowledge Management 16 (1): 1-32. https://doi. org/10.1142/S0219649217500022.

Narayanan E, Sushila DR. 2019. The effect of leadership styles on service quality improvement: the mediating role of organisational learning. AsiaPacific Journal of Innovation in Hospitality and Tourism.

Nonaka I, Hirotaka T. 1996. The knowledge-creating company: how japanese companies create the dynamics of innovation. Long Range Planning 29(4): 592. https://doi.org/10.1016/0024-
6301(96)81509-3.

Ortiz B, Mario JD, Fátima G. 2017. Relationships between structural social capital, knowledge identification capability and external knowledge acquisition. European Journal of Management and Business Economics 26(1): 48-66 https:// doi.org/10.1108/EJMBE-07-2017-004.

Osoro O, Patrick V, Joris K, Godius K. 2016. Effect of knowledge sources on firm-level innovation in Tanzania. Innovation and Development 6 (2): 259-80. https://doi.org/10.1080/2157930X.201 6.1195086.

Perkins G, Jonathan L, Robert N. 2017. The Role of organizational vision in guiding idea generation within SME contexts. Creativity and Innovation Management 26 (1): 75-90. https://doi. org/10.1111/caim.12206.

Prayogo RR, Lia N. 2019. Knowledge sharing, innovation capability, responsive capability, and marketing performance: an empirical Study at UPN 'Veteran' Jawa Timur. Indonesian Journal of Business and Entrepreneurship 5 (2): 181-91. https://doi.org/10.17358/ijbe.5.2.181.

Rahmawati T, Arif S, Ninuk P. 2018. The Effect of leadership,educationand communication channel factors on patient safety culture. Indonesian Journal of Business and Entrepreneurship 4 (3): 227-38. https://doi.org/10.17358/ijbe.4.3.227.

Rosiana L, Musa H, Eko RC. 2020. Factors affecting user behavior of technology application of management information system. Indonesian Journal of Business and Entrepreneurship 6 (3): 239-48. https://doi.org/10.17358/ijbe.6.3.239.

Saunders MNK, Philip L, Adrian T. 2019. Research Methods for Business Students. Qualitative Market Research: An International Journal. 8th Editio. Vol. 3. Harlow: Pearson. https://doi. org/10.1108/qmr.2000.3.4.215.2.

Shahzad K et al. 2013. Role of organizational vision and adaptability in knowledge management. Problems and Perspectives in Management 11 (2): 24-34.

Snyder NH, Michelle G. 1994. Leadership and vision. Business Horizons 37 (1): 1-7. https://doi. org/10.1016/S0007-6813(05)80220-4.

Weijs-Perrée M, Rianne AM, Theo A. 2020. Analysing knowledge sharing behaviour in business centres: a mixed multinomial logit model. Knowledge Management Research and Practice 18 (3): 323-35. https://doi.org/10.1080/14778238.2019 .1664269 . 
Xie X, Yanru G, Zhipeng Z, Xiaohua M. 2020. Collaborative ties and ambidextrous innovation: insights from internal and external knowledge acquisition. Industry and Innovation 27(3): 285310. https://doi.org/10.1080/13662716.2019.16 33909.

Yin RK. 2009. Case Study Research Design and Methods Fourth Edition. Applied Social Research Methods Seiries.
Yli-Renko H, Erkko A, Harry JS. 2001. Social capital, knowledge acquisition, and knowledge exploitation in young technology-based firms. Strategic Management Journal 22(6-7): 587613. https://doi.org/10.1002/smj.183.

Zhou KZ, Caroline BL. 2012. Howknowledge affects radical innovation: knowledge base, market knowledge acquisition, and internal knowledge sharing. Strategic Management Journal 33((): 1090-1102. https://doi.org/10.1002/smj.1959. 